AL IBTIDA: JURNAL PENDIDIKAN GURU MI (2021) Vol 8 (1) : 80-92

DOI: http://dx.doi.org/ 10.24235/al.ibtida.snj.v8i1.7211

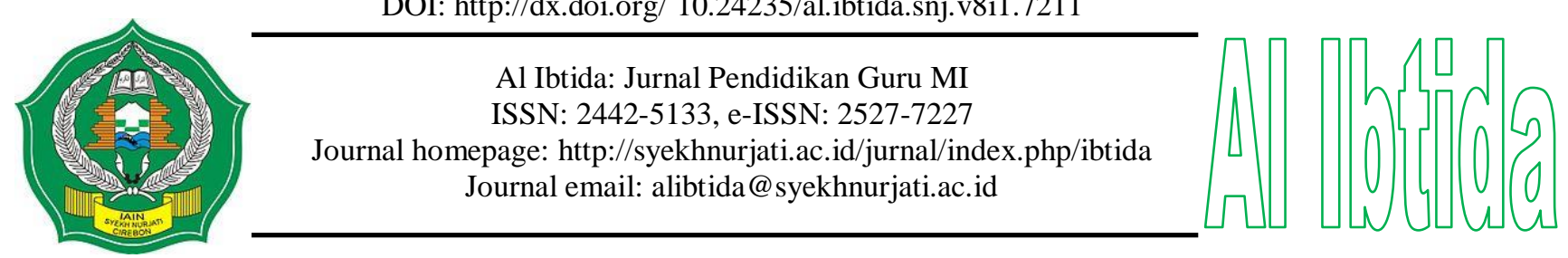

\title{
The Effect of Mastering Pedagogical Competence on the Prospective Elementary School Teachers Teaching Readiness
}

\author{
Muhammad Shabir Umar* \\ *Department of Madrasah Ibtidaiyah Teacher Education, Tarbiyah and Teacher Training Faculty, \\ Universitas Islam Negeri Alauddin Makassar, Indonesia \\ Email: m.shabiru@uin-alauddin.ac.id \\ Muljono Damopolii*** \\ **Department of Islamic Education, Tarbiyah and Teacher Training Faculty, \\ Universitas Islam Negeri Alauddin Makassar, Indonesia \\ Email: muljono.damopolii@ uin-alauddin.ac.id \\ Fitriani Nur*** \\ ***Department of Mathematics Education, Tarbiyah and Teacher Training Faculty, \\ Universitas Islam Negeri Alauddin Makassar, Indonesia \\ Email: fitrianinur@uin-alauddin.ac.id \\ Suharti $* * * *$ \\ ****Department of Mathematics Education, Tarbiyah and Teacher Training Faculty, \\ Universitas Islam Negeri Alauddin Makassar, Indonesia \\ Email: suharti.harti@uin-alauddin.ac.id
}

Received: February $28^{\text {th }}, 2021$. Accepted: June $03^{\text {rd }}, 2021$. Published: June $27^{\text {th }}, 2021$.

\begin{abstract}
This study aims to determine the description of mastering pedagogical competence, map the teaching readiness, and analyze the significant effect of mastering pedagogical competence on teaching readiness of the prospective elementary school teachers at State Islamic University (UIN) Alauddin Makassar, Indonesia. This research was ex-post-facto quantitative research. The research variables were pedagogical competence and the readiness to be a teacher. The population and sample were all of the final semester students, consisting of 80 students of Madrasah Ibtidaiyah Teacher Education Department at UIN Alauddin Makassar who had taken the Field Experience Practice program using simple random sampling. The instrument used was a Likert scale-based questionnaire. A basic linear regression was employed to analyze the data. The following are the results of this study: (1) the mean score of prospective elementary school teachers' pedagogical competence was 70.62, indicating that the pedagogical competency score was in the high category; (2) the mean score of prospective elementary school teachers' teaching readiness mapping was 72.25 , indicating that the mapping score of teaching readiness was in the high category; (3) the mean score of prospective elementary school teachers' pedagogical competence was 70.62, indicating that the pedagogical competency score was in the high category. As a result, prospective elementary school teachers' teaching preparation was influenced by their knowledge of pedagogical competence. Accordingly, prospective elementary school teachers' teaching preparation is needed
\end{abstract}


to be trained by developing pedagogical competency by constructing a learning program in the Madrasah Ibtidaiyah Teacher Education Department.

Keywords: pedagogical competence, teaching readiness, prospective elementary school teachers.

\begin{abstract}
Abstrak
Penelitian ini bertujuan untuk mendeskripsikan penguasaan kompetensi pedagogik, memetakan realitas kesiapan mengajar, dan mengetahui signifikansi pengaruh penguasaan kompetensi pedagogik terhadap kesiapan mengajar calon guru sekolah dasar di Universitas Islam Negeri (UIN) Alauddin Makassar, Indonesia. Penelitian ini adalah penelitian kuantitatif jenis ex-post facto. Variabel penelitian yaitu kompetensi pedagogik dan kesiapan menjadi guru. Populasi dan sampel yaitu seluruh mahasiswa semester akhir program studi Pendidikan Guru Madrasah Ibtidaiyah (PGMI) UIN Alauddin Makassar yang telah mengambil program praktik pengenalan lapangan (PPL), dengan sampel random sampling sejumlah 80 orang. Instrumen yang digunakan yaitu angket berbasis skala Likert. Teknik analisis data yang digunakan adalah regresi linear sederhana. Berdasarkan penelitian yang telah dilakukan, diperoleh bahwa: (1) rata-rata skor kompetensi pedagogik calon guru sekolah dasar adalah 70.62 yang berarti secara umum skor kompetensi pedagogik berada pada kategori tinggi, (2) rata-rata pemetaan kesiapan mengajar calon guru sekolah dasar adalah 72.25 yang berarti skor pemetaan kesiapan mengajar berada pada kategori tinggi, dan (3) terdapat pengaruh yang signifikan kompetensi pedagogik terhadap kesiapan mengajar calon guru sekolah dasar. Sehingga dapat disimpulkan bahwa penguasaan kompetensi pedagogik mempengaruhi kesiapan mengajar calon guru sekolah dasar. Oleh karena itu, kesiapan mengajar calon guru sekolah dasar perlu dipersiapkan secara matang melalui penguatan kompentesi pedagogik baik melalui penyiapan kurikulum pembelajaran pada jurusan Pendidikan Guru Madrasah Ibtidaiyah.
\end{abstract}

Kata kunci: kompetensi pedagogik, kesiapan mengajar, calon guru sekolah dasar.

\title{
INTRODUCTION
}

Teachers are an essential component in the learning process. They play a vital role in forming the human resources needed in the development of the nation. It is in line with the statement from Sulaiman et al. (2017) that teachers play an important role in developing human capital who will be competent and skilled workers to help strengthen the country's economy. Teachers should establish their teaching methods to ensure that the best teaching and learning process will be motivating and meaningful (Rahim et al., 2015). Therefore, the quality of teachers will also affect the quality of human resources produced. Teachers do not only function to transfer knowledge, but also to educate and guide. This complex role of teachers encourages the government to care about the quality of a teacher and to take various policies to improve teachers' quality.

One of the government's concerns on teacher quality is to formulate the competencies that must be owned by the teacher. Teachers must have high competence in terms of carrying out the tasks of the teacher (Nguyen et al., 2020; Siri et al., 2020). Teachers with a strong 
sense of competence will have the confidence to initiate teaching innovations (Averill \& Major, 2020). Competence means that a person can combine a variety of skills or functions depending on the situation in which they work (Kuivila et al., 2020). Teacher competence was positively related to students' interests (Fauth et al., 2019).

In the Law of the Republic of Indonesia Number 14 of the Year 2005 concerning Teachers and Lecturers, four competencies must be possessed by a teacher, namely: (1) Pedagogical competence regards to the teachers' understanding of students, learning design, learning implementation, learning outcome, and developing the students' potentials, (2) Personality competence is the ability that exists in a teacher to reflect his/her personality, such as patience, dignity, wisdom, and noble characters, (3) Social competence is the ability of a teacher to interact with the students, staffs, the students' parents/guardians and society, and (4) Professional competence is the ability related to the teaching profession, especially to master teaching material, various effective and appropriate learning methods.

Pedagogical competence is the primary competence that supports the learning process because it includes the ability to plan lessons and assess learning outcomes. Every teacher must possess this competency. Therefore, every prospective teacher should have this capability through the learning process that he/she has gone through in college so that he/she has the readiness to become a teacher after graduation. In the national education standards, the explanation of article 28 paragraph 3a, pedagogical competence refers to the teachers' abilities to manage the students' learning, which includes understanding students, designing and implementing the learning process, evaluating learning outcomes, and encouraging the students to actualize their various potentials (Habibullah, 2012).

Pedagogical competence includes ten sub-competencies that must be mastered by a teacher, namely: (1) getting the students' characteristics of the intellectual, emotional, and social aspects, (2) understanding learning theories and educational learning principles, (3) be able to develop a curriculum based on the subject, (4) implementing the education learning, (5) be able to use information technology in the learning process, (6) being facilitators for the students in developing their potentials, (7) be able to communicate effectively to students, (8) assessing the students' learning outcomes, (9) following up the students' learning outcomes, and (10) reflecting to improve the quality of learning (Siswanto, 2011).

Hammond \& Bransford in Rumahlatu et al., (2016) stated that professional teachers need to understand and master at least three basic knowledge of teaching which include: (1) mastering of content knowledge, (2) mastering of pedagogical knowledge, and (3) mastering of pedagogical content knowledge. Pedagogical competence affects teacher performance. The 
teacher's pedagogical competence needs to be improved so that the teacher's work morale also increases (Nellitawati, 2020). A teacher must have the ability to manage learning material and convey it to the students using several techniques, and choose the appropriate learning media (Wulandari \& Arifin, 2020). The competence possessed by a person will affect his/her desire or ability to do the work. This statement is in line with the definition stated by Hornby in Habibullah (2012) that competence is the people who have the ability, power, authority, skill, and knowledge to do what is required.

The teacher's competence in basic skills must be possessed by the teacher to do the duties as a teacher and educator. Without competence, teachers will not be able to improve their performances (Rahmatullah, 2016). The teachers' competencies affect their readiness to become teachers, especially the competence for prospective teacher students studying in education-based majors. It means that pedagogical competence has been taught to them since they are students. Therefore, they have the readiness to teach using their competencies after graduating.

Prospective teachers of Elementary Schools are more trying to prepare themselves in forming pedagogical competence because the students' characteristics of this level are more complex. With various courses and field practices that they have done during the lecture, it is expected that this pedagogical competence has been formed in every student of Madrasah Ibtidaiyah Teacher Education Department. A person's readiness to do something is a factor that affects the success of a work. Two factors affect readiness to teach or become a teacher, namely internal factors such as interests, talents, motivation, etc. Other factors that influence readiness to teach are external factors such as family environment, formal education, work experience, field experience practice, and other teaching experiences.

A teacher who has good teaching readiness is a sign of professionalism in the learning process. Being a professional teacher necessitates not only mastery of the subject matter, but also knowledge of effective educational management. It is taught in higher education, which is founded on education. Students will receive education-based science at the tertiary level, including both theoretical knowledge such as children's psychology, learning theories, and other topics, as well as practices such as microteaching, teacher training, and other teaching methods. Siswanto (2011) mentions four principles/aspects of readiness, namely: a) all development aspects of interaction, b) physical and spiritual maturity is necessary to get benefit from experiences, c) experiences have a positive influence on readiness, d) basic readiness for certain activities is formed in a particular time during the formation phases in the development period. 
Readiness in teaching is manifested from an understanding of basic teaching readiness that is a determining factor in teaching success. This readiness must be owned and mastered by prospective teachers. The primary teaching readiness includes: a) readiness to open and close the lessons in core learning activities, b) readiness to explain, c) readiness to provide reinforcement, d) readiness to use learning media and tools, e) readiness to compile scenarios/learning, f) readiness to hold variations, g) readiness to guide discussions, $h$ ) readiness to manage class, i) readiness to ask questions, and j) readiness to evaluate. Readiness to be a teacher is a condition that shows someone is ready to become a teacher/educator. The indicator of teacher readiness in teaching refers to the teacher competence in Law No. 14 of the Year 2005, one of the competencies that a teacher must have is pedagogical competence (Yulianingsih, 2018).

The research result about the contribution of teachers' pedagogical competence toward the effectiveness of teaching conducted by Ada \& Azisah (2016) indicated that there was a contribution of pedagogical competence to readiness in the teaching process. Also, Ni'mah \& Oktarina (2014) research about the influence of the professional interest of teachers on student readiness to become teachers stated that teaching readiness was determined by the ability to understand the competencies that a teacher must possess. Nellitawati (2020) research about the influence of teacher pedagogical competence on teachers' work morale, the results showed that increasing teacher pedagogical competence influenced increasing teacher morale. Rahman (2014) research about professional competence, pedagogical competence, and the performance of junior high school science teachers and the results of this study concluded that professional and pedagogical competence give a positive effect on the performance of the teacher. The findings of Adegbola's (2019) study on teachers' pedagogical competency as predictors of students' attitudes toward basic science demonstrated that teachers' pedagogical competency can have a considerable impact on students' attitudes toward basic science. And, according to Syahrial et al. (2019)'s research on pedagogic competence and Indonesian language competence in pre-service primary teachers discovered that pedagogic and language competence had a good category based on the results and discussion. This is due to the fact that a prospective teacher must possess pedagogical abilities, which are employed to assist him in studying and teaching. Unlike earlier research, this study focused on the pedagogical skills of students who participated in the PPL (teaching internship) program. As a result, the researchers want to look at the impact of pedagogical competence on students' readiness to become teachers in the Madrasah Ibtidaiyah Teacher Education Department at UIN Alauddin Makassar in the last semester. 


\section{METHODS}

This research is ex-post-facto quantitative research. It describes the causal relationship of variables related to research. The variables in this study were pedagogical competence as an exogenous variable and readiness being a teacher as an endogenous variable. The population and sample in this study were all of the last semester students of the Madrasah Ibtidaiyah Teacher Education department at UIN Alauddin Makassar, who had taken the field experience practice program by using simple random sampling with 80 people.

The instrument used to measure the variables of pedagogical competence and teaching readiness was a Likert scale-based questionnaire. The operational definition of the variables used could be explained as follows; pedagogical competence (X) was an ability that must be possessed by prospective teachers regarding students' understanding, learning design, evaluation, and development of student skill. The indicators included: 1) Educational insight, 2) Understanding of students, 3) curriculum development, 4) Educative and dialogical learning, 5) Student development, and 6) Evaluation of learning outcomes (Supriyanto, 2017). Teaching readiness $(\mathrm{Y})$ was a readiness in terms of mental, physical, and competency knowledge. The indicators were 1) Readiness to plan and prepare the learning process (PBM), 2) Readiness to manage the teaching and learning process, 3) Readiness to carry out the evaluation, 4) Readiness to implement the four pillars of education (Kurniasari, 2016). Two validators were involved who were experts in their fields and were appointed directly by the research institution. The instrument was consulted to the validators several times to get various suggestions and improvements so that it was feasible to be used. The data analysis technique used is the simple linear regression with the help of Amos used to examine more depth the indicators that affect each variable. Before testing the hypothesis, the researchers tested the prerequisites for normality and linearity.

\section{RESULTS AND DISCUSSION}

Based on the research results conducted on the prospective elementary school teachers of Madrasah Ibtidaiyah Teacher Education Department of Tarbiyah and Teacher Training Faculty at UIN Alauddin Makassar, the researchers obtained the frequency distribution table of pedagogical competence scores as the following criteria:

Table 1. The Score Distribution of Pedagogical Competence (PC)

\begin{tabular}{ccccc}
\hline No. & Score & Frequency & Percentage & Category \\
\hline 1 & $20 \leq \mathrm{PC}<45$ & 0 & 0 & Very low \\
2 & $45 \leq \mathrm{PC}<55$ & 6 & 7.5 & Low \\
3 & $55 \leq \mathrm{PC}<65$ & 13 & 16.25 & Average \\
\hline
\end{tabular}


Muhammad Shabir Umar, Muljono Damopolii, Fitriani Nur, Suharti, The Effect of Mastering Pedagogical...

\begin{tabular}{ccccc}
\hline No. & Score & Frequency & Percentage & Category \\
\hline 4 & $65 \leq \mathrm{PC}<75$ & 26 & 32.5 & High \\
5 & $75 \leq \mathrm{PC} \leq 80$ & 35 & 43.75 & Very High \\
\hline & Total & 80 & 100 & \\
\hline Mean & Std. Deviation & Variation & Minimum & Maximum \\
\hline 70.62 & 8.76 & 76.69 & 45 & 80 \\
\hline
\end{tabular}

Table 1 shows the pedagogic competence scores of the prospective elementary school teachers of the Madrasah Ibtidaiyah Teacher Education Department. None of the prospective elementary school teachers has a pedagogical competence score distribution in the very low and most of them in the very high category. Meanwhile, the standard deviation is relatively small, so that it shows the distribution of data for each sample close to the sample mean scoreThe table shows that around $77 \%$ of the prospective elementary school teachers have ideal scores in high and very high categories. It means that the level of the prospective elementary school teachers' pedagogical competence is very good. The following is the frequency distribution table of teaching readiness maps based on category.

Table 2. The Mapping Distribution of Teaching Readiness

\begin{tabular}{ccccc}
\hline No. & Score & Frequency & Percentage & Category \\
\hline 1 & $20 \leq \mathrm{PC}<45$ & 0 & 0 & Very low \\
2 & $45 \leq \mathrm{PC}<55$ & 3 & 4 & Low \\
3 & $55 \leq \mathrm{PC}<65$ & 12 & 15 & Average \\
4 & $65 \leq \mathrm{PC}<75$ & 21 & 26 & High \\
5 & $75 \leq \mathrm{PC} \leq 80$ & 44 & 55 & Very High \\
\hline & Total & 80 & 100 & \\
\hline Mean & Std. Deviation & Variation & Minimum & Maximum \\
\hline 72.25 & 7.80 & 60.90 & 50 & 80 \\
\hline
\end{tabular}

Table 2 shows the map of the prospective elementary school teachers teaching readiness of Madrasah Ibtidaiyah Teacher Education Department that in general, is in the very high category. While the standard deviation is relatively small so that the distribution of data for each sample is close to the sample mean score. This finding indicates that the mapping of the prospective elementary school teachers teaching readiness is close to the high category. Table 2 shows that approximately $81 \%$ of the prospective elementary school teachers have mappings in the high and very high categories. This result indicates that the mapping of the prospective elementary school teachers teaching readiness is very good.

The effect of pedagogical competence on the prospective elementary school teachers teaching readiness is determined by testing the hypothesis. It means to find whether there is a positive effect of mastering the pedagogical competence on teaching readiness. Also, it describes which indicators have the most significant influence on each variable. It is assumed 
necessary considering that pedagogical competence consists of several indicator compilers so that it is required to describe one by one the indicators that have an essential role in supporting the variables. The research data in the form of the pedagogical competence scores and the prospective elementary school teachers teaching readiness have met the prerequisite tests, namely normality and linearity tests.

Determining the effect of pedagogical competence on the prospective elementary school teachers teaching readiness of Madrasah Ibtidaiyah Teacher Education Department uses simple linear regression analysis with the help of Amos, the output results are as follows:

Table 3. Significant Test of Simple Linear Regression Coefficient

\begin{tabular}{lll}
\hline Model & $\mathbf{R}^{2}$ & p-value $($ sig $)$ \\
\hline $\mathrm{XY}$ & 0.366 & 0.0001 \\
\hline
\end{tabular}

Based on table $3, \mathrm{R}^{2}$ ( $\mathrm{R}$ Square) or determination is $0.366(37 \%)$. This finding shows that the contribution of pedagogical competence to the prospective elementary school teachers teaching readiness is $37 \%$, while the sig value $<0.05(0.0001<0.05)$, then $\mathrm{H} 0$ is rejected. There is $63 \%$ influenced by other factors that are not discussed in this study. Therefore, it can be concluded that pedagogical competence affects the prospective elementary school teachers teaching readiness of Madrasah Ibtidaiyah Teacher Education Department.

Table 4. Simple Linear Regression Coefficient

\begin{tabular}{|c|c|c|c|c|c|c|}
\hline \multirow[t]{2}{*}{ Model } & & \multicolumn{2}{|c|}{$\begin{array}{l}\text { Unstandard } \\
\text { Coefficients }\end{array}$} & \multirow{2}{*}{$\begin{array}{l}\text { Standard } \\
\text { Coefficients } \\
\text { Beta }\end{array}$} & \multirow{2}{*}{$\begin{array}{l}T \\
B\end{array}$} & \multirow{2}{*}{$\begin{array}{l}\text { Sig. } \\
\text { Std. Error }\end{array}$} \\
\hline & & B & Std. Error & & & \\
\hline \multirow[t]{2}{*}{1} & (Constant) & 34.662 & 5.716 & & 6.064 & 0.0001 \\
\hline & $\mathrm{PC}$ & 0.539 & 0.080 & 0.605 & 6.714 & 0.0001 \\
\hline
\end{tabular}

The simple linear regression coefficient shows that the constant coefficient value is 34.66 , and the coefficient of the independent variable $(\mathrm{X})$ is 0.54 . This result indicates that the simple linear regression equation is as follow:

$$
Y=34.66+0.54 X
$$

The prospective elementary school teacher's pedagogical competence of Madrasah Ibtidaiyah Teacher Education Department (PGMI) generally is in the high category. It means that the prospective elementary school teachers' pedagogical competence of PGMI Department has been formed in every prospective elementary school teacher during the learning process in various supporting subjects. However, there are still about $7.5 \%$ of the total research sample in the low category. Therefore, it still needs attention to maximize the 
prospective elementary school teacher's competence to support their profession in line with the vision and mission of PGMI Department.

The pedagogical competence indicators are elaborated into the questionnaire statements of pedagogical competence then distributed online via google form to 80 the prospective elementary school teachers with the criteria of having taken the field experience practice program. The descriptive result shows that $77 \%$ of the prospective elementary school teachers are in the high category and very high category. It is ideal by considering that all courses generally emphasize improving the prospective elementary school teacher's professional competence to support their profession.

Mapping the teaching readiness of PGMI prospective elementary school teachers is aimed to analyze their teaching readiness after going through the learning process. The findings of the prospective elementary school teachers teaching readiness mapping score indicate that in general, they are in the high category. It means that the prospective elementary school teachers are ready to teach after going through the learning process and attending field experience practices. However, there about $4 \%$ of the research sample includes in the low category of teaching readiness.

The indicators of teaching readiness are explained in the form of positive and negative statements of the teaching readiness questionnaire using scale1-4. The questionnaire was distributed online using Google Form to 80 prospective elementary school teachers of Madrasah Ibtidaiyah Teacher Education Department who were in the last semester and had taken field practice experience course. The descriptive analysis of the teaching readiness mapping distribution gained $81 \%$ in the high and very high categories. This result is the ideal result of mapping the prospective elementary school teachers teaching readiness to face the vision and mission of the PGMI Department. The result of simple linear regression analysis indicates a significant positive effect between pedagogical competence and teaching readiness of the prospective elementary school teachers of the PGMI Department at UIN Alauddin Makassar.

Nur (2020) explains that pedagogical competence is one of the competencies that a teacher and prospective teacher must possess. This competency also includes teaching readiness indicated by the readiness to implement the teaching knowledge and skills. Pedagogical competence is a particular competency that differentiates teachers from other professions, which shows the teachers' abilities to compile learning material to be easily understood by students (Firman et al., 2019). Pedagogical competence plays an essential role to improve teaching and learning qualities. One of them is because it can affect students' 
perceptions (Afif et al., 2020). Pedagogical competence can also improve teacher performance (Jusuf et al., 2020). It is in line with the research result conducted by Astuty (2015), which concluded that pedagogical competence had a significant effect on students' academic achievement. Pedagogical competence is a nascent concept in higher education literature (Perumal \& Maistry, 2021). Developing pedagogical competence is critical to becoming an effective teacher (Shah et al., 2019). A teacher who has adequate pedagogical competence can enhance their students' learning (Mikkonen et al., 2020), and also manage high workloads (Nilsson et al., 2017). Teachers who do not have good pedagogical competence will not be able to convey the material they teach to students (Siswanto et al., 2020).

Research conducted by Supriyanto (2017) concluded that there is an influence of pedagogic and personality competencies on students' achievement. If the teacher's pedagogical competence is good, it will affect his/her readiness in teaching so that the student's learning achievement will be better. Kurniasari (2016), in her research, also concluded that there was a positive and significant effect of field experience practice on teaching readiness. It is a part of fulfilling pedagogical competence for all students majoring in education or teacher professional qualification. One of the competencies that pre-service biology teachers need to train is pedagogical competence (Sugiharto et al., 2019). Yulianingsih (2018) also concluded that teacher attitude inside prospective educators influences the readiness to become a teacher or teaching readiness. The teacher attitude has been reflected in the pedagogical competence of future teachers. Besides, Nugroho (2017) concluded a positive and significant effect of the value of the microteaching course and Field Experience Practices on teacher readiness/teaching readiness. These subjects are compulsory subjects for teacher education students. By taking these courses, it is expected to strengthen the pedagogical competence of prospective teachers further.

\section{CONCLUSION}

Based on the results and discussion of this research, the conclusions are as follows the mean score of the prospective elementary school teachers' pedagogical competence was 70.62, which meant that the pedagogical competency score was in the high category, the mean score of the prospective elementary school teachers' teaching readiness mapping was 72.25 which indicated the mapping score of teaching readiness was in the high category, and there was a significant effect of pedagogical competence on the readiness to teach prospective elementary school teachers. Pedagogical competence indicated an important role to build student readiness in teaching. 


\section{REFERENCES}

Ada, J. H., \& Azisah, S. (2016). The Contribution of Teachers' Pedagogical Competence toward the Effectiveness of Teaching of English at MTsN Balang-Balang. ETERNAL (English, Teaching, Learning and Research Journal), 2(2), 238-251. https://doi.org/10.24252/eternal.v22.2016.a5

Adegbola, F. F. (2019). Teachers' Pedagogical Competence as Determinants of Students' Attitude towards Basic Science in South West Nigeria. Educational Research and Reviews, 14(18), 655-660. https://doi.org/10.5897/ERR2019.3761

Afif, Z. N., Ulfatin, N., Imron, A., \& Wiyono, B. B. (2020). The Improvement of Teachers' Pedagogical Competence in Recognising Students Characteristics with NeuroLinguistic Programming (NLP) in Indonesia. International Journal of Innovation, $\begin{array}{llll}\text { Creativity } \quad \text { Change, 762-780. } & \text { 13(8), }\end{array}$ https://ijicc.net/images/vol_13/Iss_8/13855_Afif_2020_E_R.pdf

Astuty, E. (2015). Implementation Analysis of Lecturer's Pedagogical Competence on Student's Academic Achievement. Journal of Management Research, 7(2), 152-168. https://doi.org/10.5296/jmr.v7i2.6834

Averill, R. M., \& Major, J. (2020). What Motivates Higher Education Educators to Innovate? Exploring Competence, Autonomy, and Relatedness-and Connections with Wellbeing. Educational Research, 62(2), 146-161. https://doi.org/10.1080/00131881.2020.1755877

Fauth, B., Decristan, J., Decker, A. T., Büttner, G., Hardy, I., Klieme, E., \& Kunter, M. (2019). The Effects of Teacher Competence on Student Outcomes in Elementary Science Education: The Mediating Role of Teaching Quality. Teaching and Teacher Education, 86, 1-14. https://doi.org/10.1016/j.tate.2019.102882

Firman, F., Tersta, F. W., Riantoni, C., \& Sekonda, F. A. (2019). An Analysis of English as a Foreign Language (EFL) Teachers' Pedagogical Competence and Readiness in Maintaining the Implementation of the 2013 Curriculum. Educational Research and Reviews, 14(13), 474-483. https://doi.org/10.5897/ERR2019.3705

Habibullah, A. (2012). Kompetensi Pedagogik Guru. EDUKASI: Jurnal Penelitian Pendidikan Agama dan Keagamaan, 10(3), 362-377. https://doi.org/10.32729/edukasi.v10i3.169

Jusuf, R., Sopandi, W., Wulan, A. R., \& Sa'ud, U. S. (2020). Analysis of Pedagogic Competence of Elementary School Teachers Based on Regional Characteristics. Proceedings of the International Conference on Educational Psychology and Pedagogy - "Diversity in Education" (ICEPP 2019), 157-160. https://doi.org/10.2991/assehr.k.200130.104

Kuivila, H. M., Mikkonen, K., Sjögren, T., Koivula, M., Koskimäki, M., Männistö, M., Lukkarila, P., \& Kääriäinen, M. (2020). Health Science Student Teachers' Perceptions of Teacher Competence: A Qualitative Study. Nurse Education Today, 84. https://doi.org/10.1016/j.nedt.2019.104210

Kurniasari, I. D. (2016). Pengaruh Minat Menjadi Guru dan Praktik Pengalaman Lapangan (PPL) terhadap Kesiapan Mengajar Mahasiswa Calon Guru Program Studi Pendidikan Akuntansi Angkatan 2012 Fakultas Ekonomi Universitas Negeri Yogyakarta [Universitas negeri Yogyakarta]. http://eprints.uny.ac.id/32815/

Mikkonen, K., Tuomikoski, A. M., Sjögren, T., Koivula, M., Koskimäki, M., Lähteenmäki, M. L., Mäki-Hakola, H., Wallin, O., Sormunen, M., Saaranen, T., Koskinen, C., 
Koskinen, M., Salminen, L., Holopainen, A., \& Kääriäinen, M. (2020). Development and Testing of an Instrument (HeSoEduCo) for Health and Social Care Educators' Competence in Professional Education. Nurse Education Today, 84. https://doi.org/10.1016/j.nedt.2019.104239

Nellitawati. (2020). The Influence of Teacher Pedagogical Competence of Teachers' Work Morale. Journal of Counseling and Educational Technology, 3(1), 29-33. https://doi.org/10.32698/0931

Nguyen, D., Ng, D., Luo, W., \& Mansor, S. (2020). Exploring the Relationships between Instructional Leadership and Teacher Competences: Singapore Primary School Teachers' Perceptions. International Journal of Leadership in Education, 1-22. https://doi.org/10.1080/13603124.2020.1731765

Ni'mah, F. U., \& Oktarina, N. (2014). Pengaruh Minat Profesi Guru, Locus of Control Internal, Peran Guru Pamong, dan Prestasi Belajar terhadap Kesiapan Mahasiswa Menjadi Guru pada Jurusan Pendidikan Ekonomi Fakultas Ekonomi Universitas Negeri Semarang. Economic Education Analysis Journal, 3(2), 336-342. https://journal.unnes.ac.id/sju/index.php/eeaj/article/view/3947

Nilsson, M., Blomqvist, K., \& Andersson, I. (2017). Salutogenic Resources in Relation to Teachers' Work-Life Balance. Work, 56(4), 591-602. https://doi.org/10.3233/WOR172528

Nugroho, I. Y. (2017). Kontribusi Mata Kuliah Micro Teaching dan Praktek Pengenalan Lapangan (PPL) terhadap Kesiapan Mengajar Mahasiswa Program Studi Pendidikan Teknik Sipil dan Perencanaan Fakultas Teknik Universitas Negeri Yogyakarta. EJournal Pend. Teknik Sipil Dan Perencanaan, 5(8), 1-7. http://journal.student.uny.ac.id/ojs/index.php/sipil/article/view/8538

Nur, A. A. (2020). Meningkatkan Kompetensi Pedagogik Guru di SD Yayasan Mutiara Gambut. In Jurnal Bahana Manajemen Pendidikan (Vol. 2, Issue 1). https://doi.org/10.24036/BMP.V2I1.3735

Perumal, K., \& Maistry, S. (2021). Pedagogical Competencies of South African Marketing Educators. Africa Education Review. https://doi.org/10.1080/18146627.2021.1878377

Rahim, S. S. A., Sulaiman, S., \& Sulaiman, T. (2015). Teacher Professional Development Through Lesson Study in Secondary Schools. Advanced Science Letters, 21(7), 2360 2364. https://doi.org/10.1166/asl.2015.6276

Rahman, M. H. (2014). Professional Competence, Pedagogical Competence and the Performance of Junior High School of Science Teachers. In Journal of Education and Practice (Vol. 5, Issue 9). www.iiste.org

Rahmatullah, M. (2016). The Relationship between Learning Effectiveness, Teacher Competence and Teachers Performance Madrasah Tsanawiyah at Serang, Banten, Indonesia. Higher Education Studies, 6(1), 169-181. https://doi.org/10.5539/hes.v6n1p169

Rumahlatu, D., Huliselan, E. K., \& Takaria, J. (2016). An Analysis of the Readiness and Implementation of 2013 Curriculum in The West Part of Seram District, Maluku Province, Indonesia. International Journal of Environmental and Science Education, 11(12), 5662-5675. http://www.ijese.net/makale/731.html

Shah, P., Madhavaram, S., \& Laverie, D. A. (2019). Developing and Demonstrating Effective Pedagogy in Marketing Education: Pedagogical Competence as an Organizing Framework for Teaching Portfolios. Marketing Education Review, 29(4), 283-304. 
https://doi.org/10.1080/10528008.2019.1657775

Siri, A., Supartha, I. W. G., Sukaatmadja, I. P. G., \& Rahyuda, A. G. (2020). Does Teacher Competence and Commitment Improve Teacher's Professionalism. Cogent Business and Management, 7(1), 1-13. https://doi.org/10.1080/23311975.2020.1781993

Siswanto. (2011). Tingkat Kesiapan Mengajar Mahasiswa Prodi Pendidikan Akuntansi Fakultas Ilmu Sosial dan Ekonomi Universitas Negeri Yogyakarta. Jurnal Pendidikan Akuntansi Indonesia, 9(2), 92-102. https://doi.org/10.21831/jpai.v9i2.969

Siswanto, H., Hariri, H., Sowiyah, S., \& Ridwan, R. (2020). The Influence of Principal Performance on Teachers' Pedagogical Competence. Journal of Social, Humanity, and Education, 1(1), 13-26. https://doi.org/10.35912/jshe.v1i1.259

Sugiharto, B., Corebima, A. D., Susilo, H., \& Ibrohim. (2019). The Pre-Service Biology Teacher Readiness in Blended Collaborative Problem Based Learning (BCPBL). International Journal of Instruction, 12(4), 113-130. https://doi.org/10.29333/iji.2019.1248a

Sulaiman, T., Hamzah, S. N., \& Rahim, S. S. A. (2017). The Relationship between Readiness and Teachers' Competency towards Creativity in Teaching among Trainee Teachers. International Journal of Social Science and Humanity, 7(8), 555-558. https://doi.org/10.18178/ijssh.2017.7.8.883

Supriyanto. (2017). Pengaruh Kompetensi Pedagogik dan Kompetensi Kepribadian Guru terhadap Prestasi Belajar PAI pada Siswa SMK Ganesha Tama Boyolali Tahun Ajaran 2016/2017 [Institut Agama Islam Negeri Surakarta]. https://docplayer.info/194399296-Tesis-pengaruh-kompetensi-pedagogik-dankompetensi-kepribadian-guru-terhadap-prestasi-belajar-pai-pada-siswa-smk-ganeshatama-boyolali-tahun-ajaran.html

Syahrial, Asrial, Kurniawan, D. A., \& Subandiyo, M. (2019). Pedagogic Competence and Indonesian Language Competence Pre-Service Teacher of Elementary Program. International Journal of Scientific \& Technology Research, 8(10), 851-856. http://www.ijstr.org/paper-references.php?ref=IJSTR-1019-23357

Wulandari, S. A., \& Arifin, Z. (2020). Digital Pedagogical Competence Evaluation of Teachers and Strategies of School Principals. Journal of Physics: Conference Series, 1469(1), 1-6. https://doi.org/10.1088/1742-6596/1469/1/012075

Yulianingsih, D. (2018). Kesiapan Menjadi Guru ditinjau Sikap Keguruan dan Persepsi Mahasiswa tentang Profesi Guru [Universitas Muhammadiyah Surakarta]. http://eprints.ums.ac.id/64212/ 